Prepared for the U.S. Department of Energy under Contract DE-AC05-76RL01830

\title{
Weighting Factors for the Commercial Building Prototypes Used in the Development of ANSI/ASHRAE/IENSA Standard 90.1- 2010
}

RE Jarnagin

GK Bandyopadhyay

January 2010

Pacific Northwest

NATIONAL LABORATORY

Proudly Operated by Battelle Since 1965 


\section{DISCLAIMER}

United States Government. Neither the United States Government nor any agency thereof, nor Battelle Memorial Institute, nor any of their employees, makes any warranty, express or implied, or assumes any legal liability or responsibility for the accuracy, completeness, or usefulness of any information, apparatus, product, or process disclosed, or represents that its use would not infringe privately owned rights. Reference herein to any specific commercial product, process, or service by trade name, trademark, manufacturer, or otherwise does not necessarily constitute or imply its endorsement, recommendation, or favoring by the United States Government or any agency thereof, or Battelle Memorial Institute. The views and opinions of authors expressed herein do not necessarily state or reflect those of the United States Government or any agency thereof.

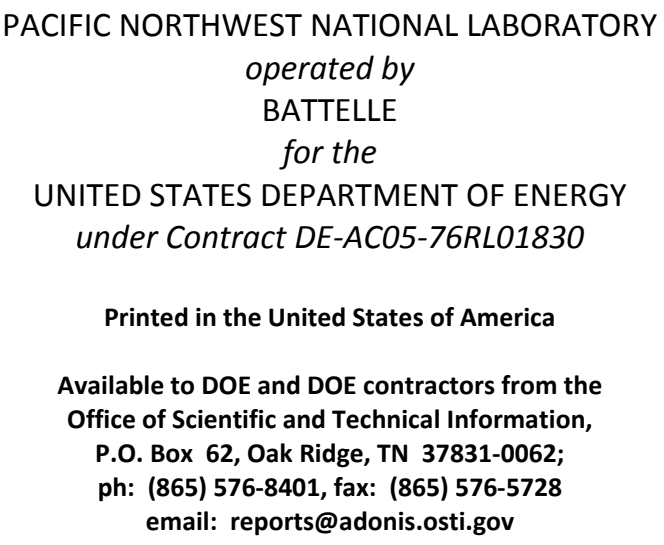

Available to the public from the National Technical Information Service, U.S. Department of Commerce, 5285 Port Royal Rd., Springfield, VA 22161 ph: (800) 553-6847, fax: (703) 605-6900

email: orders@ntis.fedworld.gov

online ordering: http://www.ntis.gov/ordering.htm

This document was printed on recycled paper.

$(8 / 00)$ 


\title{
Weighting Factors for the Commercial Building Prototypes Used in the Development of ANSI/ASHRAE/IESNA Standard 90.1-2010
}

\author{
RE Jarnagin \\ GK Bandyopadhyay
}

January 2010

Prepared for

U.S. Department of Energy

under Contract DE-AC05-76RL01830

Pacific Northwest National Laboratory

Richland, Washington 99352 


\section{Summary}

The U.S. Department of Energy (DOE), Office of Building Technologies tasked Pacific Northwest National Laboratory to develop construction weights for various commercial building categories for the purpose of estimating weighted national energy savings from the development of ANSI/ASHRAE/IESNA Standard 90.1-2010 compared to ANSI/ASHRAE/IESNA Standard 90.1-2007. Disaggregate construction volume data was acquired from the McGraw Hill Construction Database for the years 2003-2007 and analyzed to develop detailed construction weights by climate zones, subzones and by states. These weights are provided in this report and will be subsequently used in developing a weighted national energy savings estimate for the impact of the 2010 standard. 


\section{Contents}

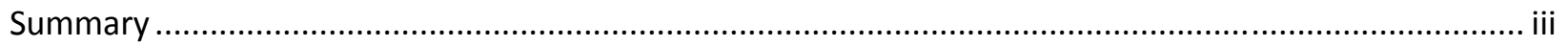

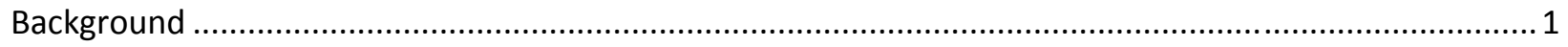

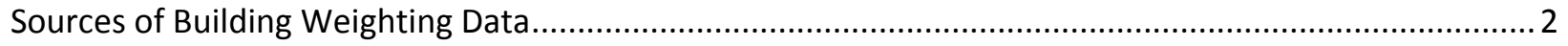

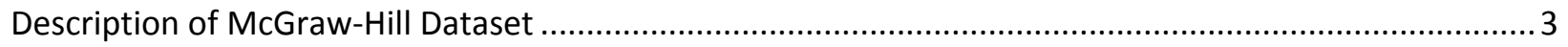

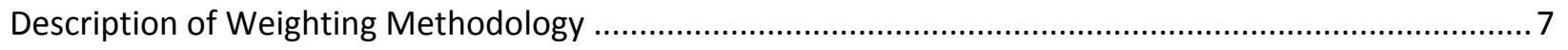

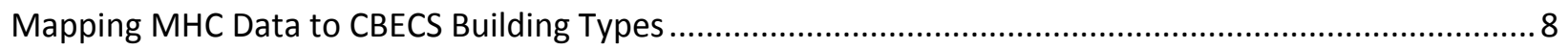

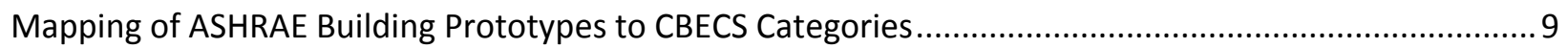

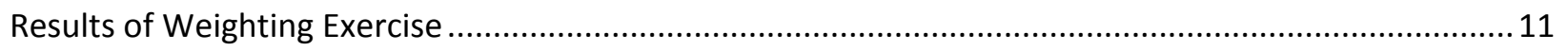

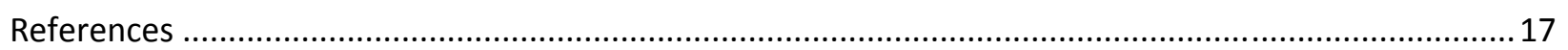




\section{Figures}

Figure 1 Percentage Construction Volume by Climate Zone ....................................................... 11

Figure 2 Percentage Construction Volume by Primary Building Categories .............................. 12

\section{Tables}

Table 1 List of fields and data types in the MHC dataset ......................................................... 4

Table 2 Mapping of MHC Types to CBECS Building Categories .................................................. 5

Table 3 Construction Volume Weights for All Building Prototypes and Climate Zones and

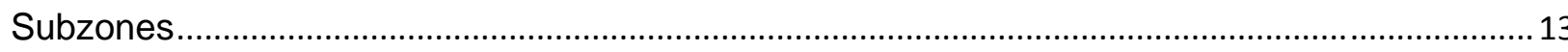

Table 4 Construction Volume Area for All Building Prototypes and Climate Zones and

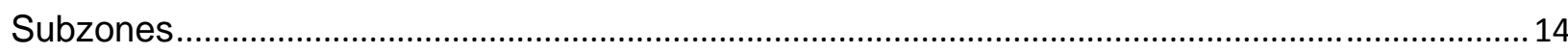

Table 5 ASHRAE Prototype Building Construction Number of Projects .......................................15

Table 6 Prototype Building Construction Volume by State $\left(1,000 \mathrm{ft}^{2}\right)$........................................16 


\section{Background}

As part of the development of American National Standards Institute (ANSI)/American Society of Heating, Refrigerating and Air-Conditioning Engineers (ASHRAE)/Illuminating Society of North America (IESNA) Standard 90.1-2010, 16 building prototypes were created based on the set of benchmark buildings ${ }^{1}$ developed by the U.S. Department of Energy's (DOE) Office of Building Technology. The intent was to use these prototype buildings for analyzing potential energy savings of various measures, as well as for establishing the energy savings estimates attributable to the 2010 version of the standard compared to the 2004 version of the standard (ASHRAE 2004). To establish energy savings across the commercial buildings sector, a set of factors were developed to weight the results of each building prototype in each climate zone used in Standard 90.1 proportionately into the national aggregate energy savings estimates. This document discusses the development and application of those building weights. The prototypes developed in this effort and the building weights for those prototypes will be submitted for inclusion in upcoming releases of the DOE benchmark buildings.

${ }^{1}$ See http://www1.eere.energy.gov/buildings/commercial initiative/benchmark models.html for discussion of DOE's Benchmark buildings. 


\section{Sources of Building Weighting Data}

To develop credible national weighting factors for commercial building construction, a data source was required that was national in scope, relatively transparent, defensible in nature, and provided a level of disaggregation necessary to apply to the various building prototypes in the various climate zones used in Standard 90.1. After a fairly rigorous search, only two data sources seemed to be candidates for this work. Those sources were the U.S. Energy Information Agency's (EIA) 2003 Commercial Building Energy Consumption Survey (CBECS 2003) and the McGraw-Hill Construction Projects Starts Database (MHC) ${ }^{2}$.

The CBECS survey data set is publicly available for free from the EIA website and represents a sample of 5,215 members of the current commercial building stock. This survey is conducted every 4 years and is designed to be a statistically valid sample of the existing commercial building population in the U.S. As part of the survey, the EIA collects a wealth of information on building use and characteristics, including energy use within the buildings. The strength of the CBECS data set is in the characteristic and operational data collected on the buildings in the sample set. Weaknesses of the data set are the relatively small sample size, the masking that is done to protect privacy of the owner/occupant but which renders the location of any sample building obscure, and that the sample covers only existing buildings. In addition, the data set only covers commercial buildings and does not include high rise residential buildings, which are contained in the scope of Standard 90.1.

The MHC data set is drawn from permit data on new commercial building starts in the U.S. and represents an overwhelming sample of over $90 \%$ of the new commercial buildings. The data collected by McGraw-Hill is used by federal agencies such as the U.S. Census Bureau, the Federal Reserve and the U.S Department of Health and Human Services (HHS). Collection of the data is done in real time, and the collection process is independently monitored to ensure coverage of most of the commercial construction in the U.S. The strength of this data lies in the number of samples, the frequency of data collection, the detailed data on location of the projects down to the local community level, and the fact that high rise residential buildings are included (contrary to CBECS) in the data set. A weakness of the data set is the lack of characteristic data on the buildings contained in the data set.

Based on the need for accurate weighting data that could be applied to the specific geographic climate zones used by Standard 90.1 and the states and local jurisdictions around the country, the decision was made that DOE's Building Energy Codes Program (BECP) would acquire McGraw-Hill construction (MHC) data to develop the weighting factors. Data for calendar years 2003 through 2007 was acquired from McGraw-Hill at the individual project level. This data is also available at various levels of aggregation, such as state level or statistical metropolitan area (SMA). However, to provide full flexibility in manipulating the data to establish detailed weighting factors the choice of individual project records represents the ideal solution.

\footnotetext{
${ }^{2}$ See http://dodge.construction.com/ for description of the McGraw Hill construction data.
} 


\section{Description of McGraw-Hill Dataset}

The McGraw-Hill construction dataset became the primary source data for generating the weighting factors for the commercial building prototypes for ASHRAE. The MHC dataset acquired by BECP covered construction data for all new buildings, as well as additions to existing facilities over 5 years (2003-2007), and represents a set of 254,158 individual records of construction of commercial buildings across the U.S. covering a total of 8.2 billion square feet.

Each record contains values for 15 independent fields for a specific construction project. The description of the fields, data types and other features of the database is presented in Table 1. The dataset, as delivered, did not have any native unique key field to be used as an index in the database. To facilitate subsequent processing, a unique indexed field was constructed and added to each record. The first four digits of this index correspond to the year of construction, and the remaining six digits correspond to a serial number specific for the year.

The key fields of the MHC dataset used in this analysis include:

- Project Type

- New/Add

- Project Title

- Square Footage Area

- Number of Stories

- Dwelling Units. 
Table 1 List of fields and data types in the MHC dataset

\begin{tabular}{clcc}
\hline Serial No & Dodge Data Field & Type & Size \\
\hline 1 & Project Title & Text & 255 \\
2 & Project Addr1 & Text & 255 \\
3 & Project Addr2 & Text & 255 \\
4 & Project City & Text & 255 \\
5 & Project State & Text & 255 \\
6 & Project Zipcode & Text & 255 \\
7 & Project County & Text & 255 \\
8 & Start YearMo & Text & 255 \\
9 & New/Add & Text & 255 \\
10 & Project Type & Text & 255 \\
11 & Ownership & Text & 255 \\
12 & Stories (Strys) & Integer & 4 \\
13 & Square Footage ('000s) & Double & 8 \\
14 & Value ('000s) & Double & 8 \\
15 & Dwelling Units & Double & 8 \\
\hline
\end{tabular}

The Project Type field describes the type of project (building use) utilizing one of the 50 building types listed in Table 2. No separate category definition (as is available for CBCES types) was provided by McGraw-Hill, so the underlying use of the building was inferred from the description. The New/Add field indicated whether the project was new construction or an addition to an existing facility. The web form appearing in the MHC website for entering project information indicated two additional project types (project renovation/retrofit and interior completion) were available, but data for these project types were not acquired.

The number of stories in the building and number of dwelling units for apartments /condos were also available. The Project Title field generally was descriptive, and included either an associated chain/ franchise name (Wal-Mart, Target, Burger King, etc.) and/or name of the location and/or proposed use of the building (parking garage, store, etc.). This field was used extensively in conjunction with the Project Type field for data analysis. The Square Footage field was used as the basis for all weight calculations. 
Table 2 Mapping of MHC Types to CBECS Building Categories

\begin{tabular}{|c|c|c|c|c|}
\hline $\begin{array}{l}\text { Category } \\
\text { Number }\end{array}$ & MHC_Project_Type & $\begin{array}{c}\text { Dominant CBECS Building } \\
\text { Categories }\end{array}$ & $\begin{array}{l}\text { Mapping } \\
\text { Action* }\end{array}$ & $\begin{array}{l}\text { Number of } \\
\text { Projects }\end{array}$ \\
\hline 1 & Sunday Schools & Public Assembly & A & 32 \\
\hline 2 & YMCA/YWCA & Public Assembly & A & 22 \\
\hline 3 & Airline Terminals & Public Assembly & A & 377 \\
\hline 4 & Apartments 5+ Units, 4+ Stories & $\begin{array}{l}\text { Mid/High Rise Aptmnts (Not } \\
\text { in CBECS) }\end{array}$ & DA & 7,502 \\
\hline 5 & Arenas/Coliseums & Public Assembly & $A$ & 264 \\
\hline 6 & Armories/Military Buildings & Office, Public Assembly & DA & 916 \\
\hline 7 & Auditoriums & Public Assembly & A & 240 \\
\hline 8 & Auto Service & Service, Mercantile (Other) & DA & 9,200 \\
\hline 9 & Banks/Financial, 1-3 stories & Office & A & 9,200 \\
\hline 10 & Banks/Financial, 4+ stories & Office & $A$ & 63 \\
\hline 11 & Bowling Alleys & Public Assembly & A & 68 \\
\hline 12 & Bus, Truck and Railroad Terminals & Public Assembly & A & 338 \\
\hline 13 & Capitols/Court Houses/City Halls & Office, Public Assembly & DA & 1,466 \\
\hline 14 & $\begin{array}{l}\text { Clinics/Nursing Convalescent } \\
\text { Facilities }\end{array}$ & $\begin{array}{l}\text { Health Care (Inpatient and } \\
\text { Outpatient) }\end{array}$ & DA & 12,002 \\
\hline 15 & Clubs and Lodges & Public Assembly, Lodging & DA & 4,059 \\
\hline 16 & $\begin{array}{l}\text { Colleges/Universities Except } \\
\text { Community }\end{array}$ & Education & A & 2,655 \\
\hline 17 & Communications Buildings & Other, Office & DA & 510 \\
\hline 18 & Community Colleges & Education & A & 655 \\
\hline 19 & Detention Facilities & Public Order and Safety & DA & 902 \\
\hline 20 & Dormitories & Lodging & A & 1,969 \\
\hline 21 & Exhibition Halls & Public Assembly & A & 700 \\
\hline 22 & Food/Beverage Service & $\begin{array}{l}\text { Food Service, Mercantile } \\
\text { (Other) }\end{array}$ & $\mathrm{DA}$ & 15,805 \\
\hline 23 & $\begin{array}{l}\text { Freight Terminals, Truck Rail and } \\
\text { Marine }\end{array}$ & Public Assembly & A & 255 \\
\hline 24 & Funeral/Internment Facilities & Service, Public Assembly & DA & 523 \\
\hline 25 & Gyms/Field Houses/Indoor Pools & Public Assembly & A & 2,953 \\
\hline 26 & Hospitals & Health Care (Inpatient) & A & 3,626 \\
\hline 27 & $\begin{array}{l}\text { Hotels/Motels (Stories Unknown or } \\
\text { Alts) }\end{array}$ & Lodging & $A$ & 36 \\
\hline 28 & Hotels/Motels 1-3 Stories & Lodging & A & 2,049 \\
\hline 29 & Hotels/Motels 4+ Stories & Lodging & A & 2,019 \\
\hline 30 & $\begin{array}{l}\text { Houses of Worship, Other } \\
\text { Religious Bldgs }\end{array}$ & Religious Worship & $A$ & 11,939 \\
\hline 31 & Junior High Schools & Education & A & 2,287 \\
\hline 32 & Laboratories/Testing/R\&D & Other & A & 775 \\
\hline 33 & Libraries & Public Assembly & $A$ & 1,747 \\
\hline 34 & $\begin{array}{l}\text { Miscellaneous } \\
\text { Amusement/Recreational }\end{array}$ & Public Assembly & A & 8,989 \\
\hline 35 & $\begin{array}{l}\text { Miscellaneous Non-Residential } \\
\text { Buildings }\end{array}$ & Other & $A$ & 7 \\
\hline 36 & Museums & Public Assembly & A & 592 \\
\hline 37 & Offices, 1-3 stories & Office & A & 49,067 \\
\hline 38 & Offices, 4+ stories & Office & A & 1,501 \\
\hline 39 & Parking Garages & Other & $\mathrm{A}$ & 7,184 \\
\hline
\end{tabular}




\begin{tabular}{|c|l|l|c|c|}
\hline $\begin{array}{c}\text { Category } \\
\text { Number }\end{array}$ & \multicolumn{1}{|c|}{ MHC_Project_Type } & \multicolumn{1}{|c|}{$\begin{array}{c}\text { Dominant CBECS Building } \\
\text { Categories }\end{array}$} & $\begin{array}{c}\text { Mapping } \\
\text { Action* }\end{array}$ & $\begin{array}{c}\text { Number of } \\
\text { Projects }\end{array}$ \\
\hline 40 & Police/Fire Stations & Public Order and Safety & A & 4,068 \\
\hline 41 & Post Offices & Service & A & 149 \\
\hline 42 & Primary Schools & Education & A & 8,332 \\
\hline 43 & Refrigerated Warehouses & Warehouse and Storage & A & 646 \\
\hline 44 & Senior High Schools & Education & A & 5,873 \\
\hline 45 & Shopping Centers & Mercantile (Malls) & A & 5,898 \\
\hline 46 & Special Schools & Education & A & 3,873 \\
\hline 47 & Stores & Mercantile (Malls), & Major & 35,277 \\
& & Mercantile (Other), Service, & DA & \\
\hline 48 & Theaters & Food service & A & 941 \\
\hline 49 & Vocational Schools & Public Assembly & A & 561 \\
\hline 50 & Warehouses (Non-Refrigerated) & Wducation & A & 24,046 \\
\hline
\end{tabular}

*A: Aggregation, DA: Disaggregation 


\section{Description of Weighting Methodology}

The weighting methodology utilized data from both CBECS and MHC. Data from CBECS is used for providing input assumptions for the energy simulation analysis of the prototype buildings, while the data from MHC is used directly for weighting. To tie these two datasets together with the building prototypes requires a mapping from MHC to CBECS categories and then, a second mapping of the CBECS to the building prototypes.

Each building prototype, with the exception of residential prototypes, corresponds to either a CBECS main category or a CBECS subcategory. In the first stage of mapping, the Project Type description from the $\mathrm{MHC}$ dataset was used to map each building to a CBECS building category. In the next step, the ASHRAE building prototypes were mapped to a CBECS category or a subcategory. When the ASHRAE building prototype matched with a principal CBECS category, the aggregate square feet area for the given ASHRAE building prototype was obtained by summing the individual areas from the MHC dataset for all the buildings in that CBECS category. This is a relatively straightforward process.

When the building type matched to a CBECS subcategory, the CBECS main category data was partitioned into the required subcategories using the MHC types to the extent possible. When this was not possible, the data in the Project Description field was used for the mapping. When several ASHRAE building prototypes correspond to one CBECS main category, usually data in other fields like area and number of stories etc. were examined to identify the appropriate prototype for the particular project. 


\section{Mapping MHC Data to CBECS Building Types}

The MHC building dataset has been mapped to 15 CBECS building categories using the field values for the given project over multiple fields. As seen from Table 2, for several CBECS categories the process of mapping involved aggregation of count and area data over several MHC Building types. For example, the CBECS category of Education data aggregation was done over five different MHC types (elementary schools, special school, etc). This was, however, a simpler process than disaggregation.

Disaggregation was required for the MHC building type Stores, which was mapped to the four different CBECS categories of food sales, mercantile (other), mercantile (mall) and service. This step involved parsing the Project Title field by searching for a criteria word and then updating the data base by populating the CBECS category field. The criteria word was based on initial inspection and often included a chain or franchise identifier or a generic word. This process was largely successful in resolving the mapping. However, in case of $\mathrm{MHC}$ project type Store, for a significant number of projects, the description fields have minimal information (e.g., 'retail building', 'stores' etc). This was mapped to CBECS category mercantile (other) because this was the dominant category to which the MHC building type was mapped.

After all of the previous steps were performed, there remained 3,353 records that could not easily be mapped to CBECS categories. These records represented $1.3 \%$ of the total number of records in the dataset, but a significant percentage of the total square feet. The reason these records could not be categorized was because of incomplete or conflicting information in the MHC data set. After considering the option of discarding the data, a scheme was devised that allowed the weighting data to be utilized in a manner consistent with the rest of the records. The assumption was made that the remaining records would represent buildings statistically in the same proportion as the records that were previously categorized from the Stores category. Utilizing this approach the remaining records were randomly assigned to one of the four subcategories of Stores so that all of the square footage from the dataset was accounted for. 


\section{Mapping of ASHRAE Building Prototypes to CBECS Categories}

Determining the weightings for the building prototypes required a mapping of the prototypes to their representative CBECS building categories. For some of the prototypes, this mapping was straight forward because of one-to-one correspondence between the prototype building and the CBECS category. These are:

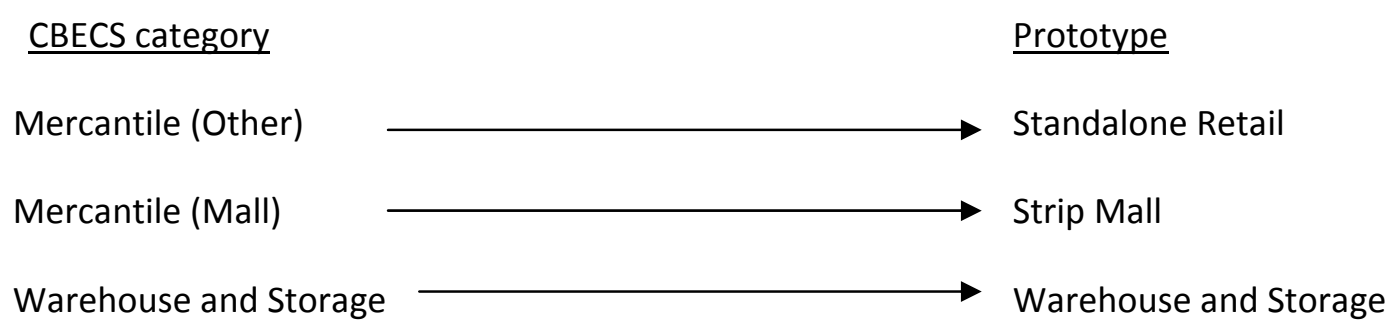

For others, all the buildings for a particular CBECS category were partitioned into different subsets for each building prototype according to a given criteria. These include:

- CBECS category Office to three prototypes (Large, Medium and Small)

- CBECS category Education to two prototypes (Primary and Secondary)

- CBECS category Healthcare to two prototypes (Hospital and Outpatient)

- CBECS category Food Service to two prototypes (Restaurant and Fast food)

- CBECS category Lodging to two prototypes (Large and Small).

In addition to the above, the apartment buildings in the MHC dataset, which are not included in CBECS, needed to be partitioned into high-rise and mid-rise apartments to match the building prototypes. For the set of apartments, buildings of four to six stories were categorized as mid-rise, and the buildings with seven stories and above were categorized as high rise.

For Office buildings the three building prototypes were all mapped to the Office category, but then needed to be partitioned into the weights from the MHC data. Several approaches were suggested that would have assigned the office prototypes to the MHC based on a review of the statistical distribution of office sizes in the MHC dataset. This approach, while somewhat arbitrary in final execution, would have been more satisfying technically because it could easily be updated as new MHC data was acquired. However, the DOE Office of Buildings Technology work on the Benchmark Buildings conducted by the National Renewable Energy Laboratory (Deru et al. 2006) established a precedent for dividing the office buildings by number of stories and square footage, and subsequently this approach was used to maintain consistency across the program areas. Use of this approach partitioned the data for the prototypes as being Small Office (one story), Medium Office (four stories) and Large Office (five stories and up with $>20,000 \mathrm{ft}^{2}$ ). 
For Education buildings, all primary schools identified in the MHC building types were considered to correspond to the ASHRAE primary school prototype, while all the remaining education buildings were considered as secondary schools.

For the Healthcare buildings, all hospitals identified in the MHC building type (type \#26) were considered to correspond to hospital prototype. Out of the remaining health care buildings, there were several records that included the 'hospital' keyword in the project description, and these were considered as hospitals as well. The rest were considered as an outpatient facility.

For assigning appropriate prototypes to the Food Service category, the MHC project description field was parsed and compared against a list of typical main full service restaurants. Those matching these criteria were categorized as Restaurants. The remaining projects were categorized as Fast Food restaurants.

For assigning appropriate prototypes to the Lodging category, the area parameters were used. The small hotel prototype has an area of $43,000 \mathrm{ft}^{2}$, while the large hotel has an area of $100,000 \mathrm{ft}^{2}$. For this exercise, all hotels with an area greater than $60,000 \mathrm{ft}^{2}$ were considered as large hotels, and all the remaining lodging buildings were considered as small hotels.

The outcome of all of the mapping and partitioning of data results in each $\mathrm{MHC}$ project record being assigned to either one of the prototype buildings being used for the simulation analysis or being assigned to CBECS categories of buildings for which there are no prototypes. Additional fields were added to the database to allow tracking of these assignments including an indication of when a record was randomly assigned to a CBECS category and building prototype. 


\section{Results of Weighting Exercise}

Weights, based on square footage, were assigned by climate zone (i.e., 1-8), location (i.e., states) and by building prototype or category of building type (i.e., Large Office, Food Service). This assignment allows the production of multiple reports showing numbers of projects, square footage and percentage weights.

Figure 1 indicates the weighting of the construction volume over the eight climate zones. From this graphic, it is easy to see that the bulk of the construction occurs in climate zones 3 and 4 (roughly 50\% of the construction). With the addition of climate zone 5 , roughly $73 \%$ of the construction volume is represented, and the addition of climate zone 2 pushes this to over $90 \%$ of the construction volume nationally.

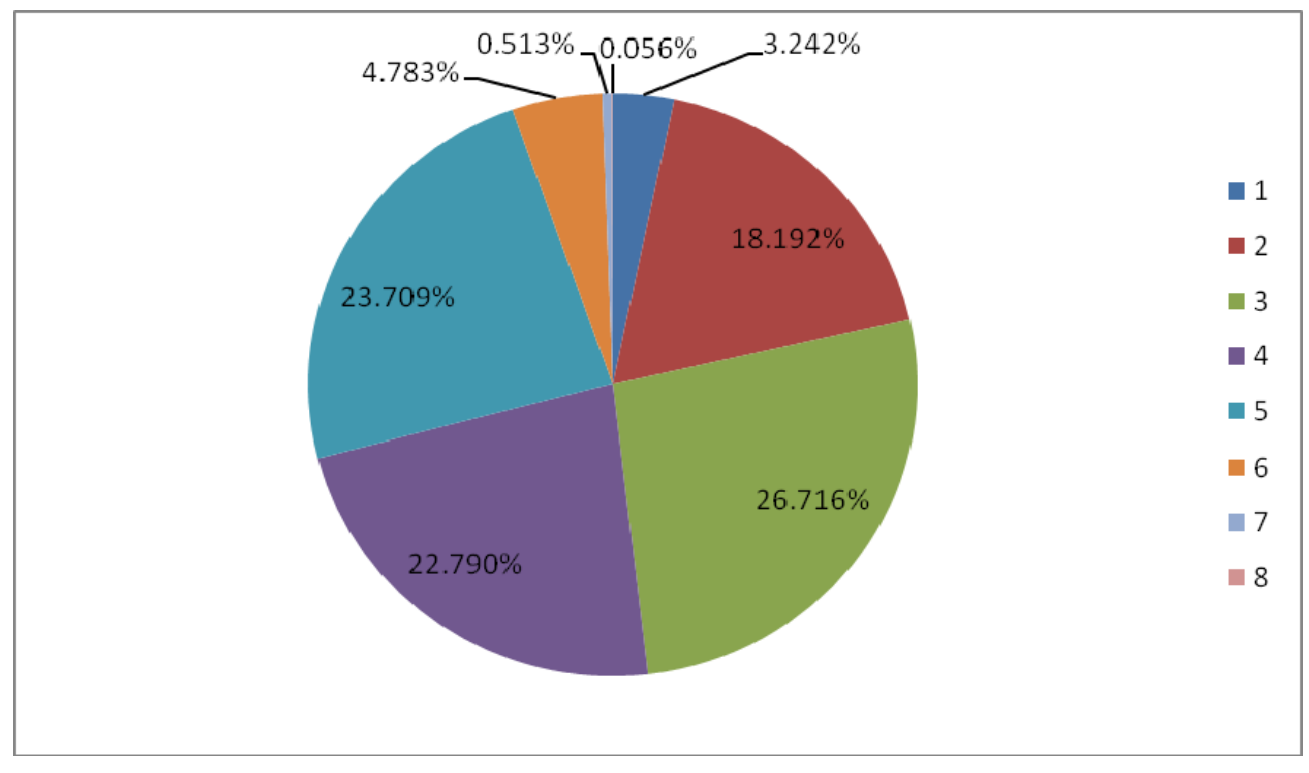

Figure 1 Percentage Construction Volume by Climate Zone

Figure 2 indicates the weighting of the construction volume over the eight primary CEBECS categories being used for the prototype buildings. It can easily be seen that Retail (CBECS Mercantile) is the dominant category of building types followed by Warehouses and Residential. Education and Offices are the next two most important categories. Historically the Office building type has dominated building category weights, but recent commercial construction has shown changes that result in other building types being more predominant in the construction industry. 


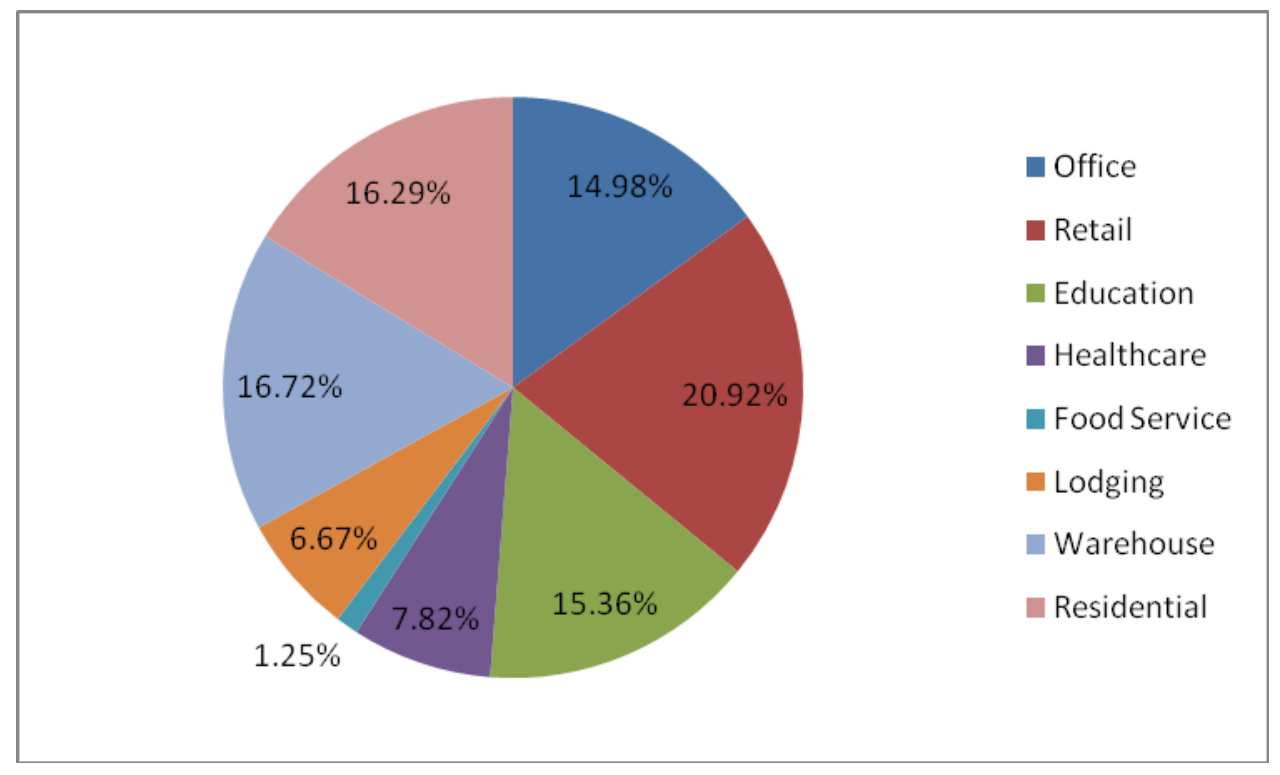

Figure 2 Percentage Construction Volume by Primary Building Categories

Probably of primary interest is the actual set of construction weights generated from the MHC dataset. Table 3 contains the weights by building prototype and by climate zone and subzone. This allows the reader to see the relative weights of each prototype building in each climate. These weights will be utilized to scale up the results of building energy simulations in each climate location to develop national estimates of energy savings.

Three additional tables are provided to help in understanding the construction trends in the U.S. The first additional table, Table 4, contains the construction volume area by building prototype and by climate zone and subzones. Table 5 shows the number of actual construction projects that were started during the 2003-2007 period categorized by prototype building type and climate zone. Similar to the construction weights, the high impact climate zones are 2 through 5 . Table 6 breaks down the construction volume for the U.S. by state and CBECS building category. From an overall construction perspective, the leading states were Florida, with 890 million $\mathrm{ft}^{2}$; California, with 780 million $\mathrm{ft}^{2}$; and Texas, with 777 million $\mathrm{ft}^{2}$. 
Table 3 Construction Volume Weights for All Building Prototypes and Climate Zones and Subzones

\begin{tabular}{|c|c|c|c|c|c|c|c|c|c|c|c|c|c|c|c|c|c|}
\hline Number & ASHRAE & 1_moist & 2_dry & 2_moist & 3_dry & 3_marine & 3_moist & 4_dry & 4_marine & 4_moist & 5_dry & 5_moist & 6_dry & 6_moist & 7 & 8 & National \\
\hline 1 & Large Office & $0.102 \%$ & $0.061 \%$ & $0.326 \%$ & $0.285 \%$ & $0.117 \%$ & $0.445 \%$ & $0.000 \%$ & $0.154 \%$ & $1.132 \%$ & $0.121 \%$ & $0.442 \%$ & $0.000 \%$ & $0.133 \%$ & $0.011 \%$ & $0.000 \%$ & $3.327 \%$ \\
\hline 2 & Medium Office & $0.129 \%$ & $0.292 \%$ & $0.813 \%$ & $0.715 \%$ & $0.136 \%$ & $0.766 \%$ & $0.036 \%$ & $0.196 \%$ & $1.190 \%$ & $0.342 \%$ & $1.060 \%$ & $0.035 \%$ & $0.298 \%$ & $0.033 \%$ & $0.007 \%$ & $6.047 \%$ \\
\hline 3 & Small Office & $0.084 \%$ & $0.289 \%$ & $1.064 \%$ & $0.475 \%$ & $0.078 \%$ & $0.963 \%$ & $0.047 \%$ & $0.123 \%$ & $0.936 \%$ & $0.322 \%$ & $0.920 \%$ & $0.030 \%$ & $0.241 \%$ & $0.032 \%$ & $0.005 \%$ & $5.608 \%$ \\
\hline 4 & Standalone Retail & $0.224 \%$ & $0.507 \%$ & $2.220 \%$ & $1.250 \%$ & $0.191 \%$ & $2.386 \%$ & $0.119 \%$ & $0.428 \%$ & $2.545 \%$ & $0.792 \%$ & $3.429 \%$ & $0.091 \%$ & $0.948 \%$ & $0.109 \%$ & $0.014 \%$ & $15.254 \%$ \\
\hline 5 & Strip Mall & $0.137 \%$ & $0.254 \%$ & $0.991 \%$ & $0.626 \%$ & $0.103 \%$ & $1.021 \%$ & $0.023 \%$ & $0.107 \%$ & $1.008 \%$ & $0.201 \%$ & $1.023 \%$ & $0.016 \%$ & $0.153 \%$ & $0.007 \%$ & $0.001 \%$ & $5.669 \%$ \\
\hline 6 & Primary School & $0.064 \%$ & $0.164 \%$ & $0.933 \%$ & $0.446 \%$ & $0.048 \%$ & $0.944 \%$ & $0.030 \%$ & $0.094 \%$ & $0.895 \%$ & $0.224 \%$ & $0.920 \%$ & $0.037 \%$ & $0.168 \%$ & $0.023 \%$ & $0.003 \%$ & $4.994 \%$ \\
\hline 7 & Secondary School & $0.160 \%$ & $0.230 \%$ & $1.523 \%$ & $0.819 \%$ & $0.109 \%$ & $1.893 \%$ & $0.063 \%$ & $0.243 \%$ & $2.013 \%$ & $0.438 \%$ & $2.282 \%$ & $0.086 \%$ & $0.415 \%$ & $0.075 \%$ & $0.012 \%$ & $10.361 \%$ \\
\hline 8 & Hospital & $0.040 \%$ & $0.096 \%$ & $0.479 \%$ & $0.273 \%$ & $0.039 \%$ & $0.468 \%$ & $0.022 \%$ & $0.106 \%$ & $0.615 \%$ & $0.218 \%$ & $0.812 \%$ & $0.024 \%$ & $0.221 \%$ & $0.034 \%$ & $0.001 \%$ & $3.448 \%$ \\
\hline 9 & Outpatient Health Care & $0.037 \%$ & $0.134 \%$ & $0.567 \%$ & $0.275 \%$ & $0.061 \%$ & $0.581 \%$ & $0.023 \%$ & $0.181 \%$ & $0.818 \%$ & $0.218 \%$ & $1.058 \%$ & $0.033 \%$ & $0.342 \%$ & $0.039 \%$ & $0.002 \%$ & $4.371 \%$ \\
\hline 10 & Restaurant & $0.009 \%$ & $0.025 \%$ & $0.106 \%$ & $0.047 \%$ & $0.006 \%$ & $0.111 \%$ & $0.006 \%$ & $0.010 \%$ & $0.127 \%$ & $0.031 \%$ & $0.143 \%$ & $0.004 \%$ & $0.031 \%$ & $0.004 \%$ & $0.000 \%$ & $0.660 \%$ \\
\hline 11 & Fast Food Restaurant & $0.008 \%$ & $0.020 \%$ & $0.092 \%$ & $0.063 \%$ & $0.007 \%$ & $0.102 \%$ & $0.005 \%$ & $0.014 \%$ & $0.089 \%$ & $0.026 \%$ & $0.128 \%$ & $0.003 \%$ & $0.025 \%$ & $0.004 \%$ & $0.000 \%$ & $0.587 \%$ \\
\hline 12 & Large Hotel & $0.109 \%$ & $0.125 \%$ & $0.621 \%$ & $0.793 \%$ & $0.106 \%$ & $0.635 \%$ & $0.037 \%$ & $0.123 \%$ & $0.958 \%$ & $0.200 \%$ & $0.919 \%$ & $0.058 \%$ & $0.227 \%$ & $0.038 \%$ & $0.004 \%$ & $4.951 \%$ \\
\hline 13 & Small hotel/motel & $0.010 \%$ & $0.030 \%$ & $0.288 \%$ & $0.114 \%$ & $0.022 \%$ & $0.268 \%$ & $0.020 \%$ & $0.039 \%$ & $0.315 \%$ & $0.089 \%$ & $0.365 \%$ & $0.031 \%$ & $0.107 \%$ & $0.020 \%$ & $0.004 \%$ & $1.721 \%$ \\
\hline 14 & Non-refrigerated warehouse & $0.349 \%$ & $0.580 \%$ & $2.590 \%$ & $2.298 \%$ & $0.154 \%$ & $2.966 \%$ & $0.068 \%$ & $0.435 \%$ & $2.446 \%$ & $0.688 \%$ & $3.580 \%$ & $0.049 \%$ & $0.466 \%$ & $0.043 \%$ & $0.002 \%$ & $16.716 \%$ \\
\hline 15 & High-rise apartment & $1.521 \%$ & $0.076 \%$ & $1.512 \%$ & $0.741 \%$ & $0.173 \%$ & $0.652 \%$ & $0.000 \%$ & $0.358 \%$ & $2.506 \%$ & $0.115 \%$ & $1.163 \%$ & $0.016 \%$ & $0.125 \%$ & $0.008 \%$ & $0.000 \%$ & $8.967 \%$ \\
\hline 16 & Mid-rise apartment & $0.257 \%$ & $0.093 \%$ & $1.094 \%$ & $0.862 \%$ & $0.260 \%$ & $0.825 \%$ & $0.022 \%$ & $0.371 \%$ & $1.694 \%$ & $0.318 \%$ & $1.122 \%$ & $0.056 \%$ & $0.313 \%$ & $0.032 \%$ & $0.000 \%$ & $7.321 \%$ \\
\hline & Totals & $3.242 \%$ & $2.975 \%$ & $15.217 \%$ & $10.081 \%$ & $1.609 \%$ & $15.025 \%$ & $0.522 \%$ & $2.981 \%$ & $19.286 \%$ & $4.344 \%$ & $19.366 \%$ & $0.569 \%$ & $4.214 \%$ & $0.513 \%$ & $0.056 \%$ & $100.0 \%$ \\
\hline
\end{tabular}


Table 4 Construction Volume Area for All Building Prototypes and Climate Zones and Subzones

\begin{tabular}{|c|c|c|c|c|c|c|c|c|c|c|c|c|c|c|c|c|c|}
\hline erial No & ASHRAE & 1_moist & 2_dry & 2_moist & 3_dry & 3_marine & 3_moist & 4_dry & 4_marine & 4_moist & 5 dry & 5 moist & 6_dry & 6 moist & 7 & 8 & Total \\
\hline 1 & Large Office & 6,733 & 4,019 & 21,549 & 18,833 & 7,718 & 29,439 & & 10,170 & 74,886 & 8,006 & 29,259 & & 8,808 & 714 & & 220,134 \\
\hline 2 & Medium Office & 8,564 & 19,319 & 53,760 & 47,312 & 8,987 & 50,661 & 2,409 & 12,956 & 78,714 & 22,628 & 70,100 & 2,304 & 19,744 & 2,182 & 452 & 400,091 \\
\hline 3 & Small Office & 5,553 & 19,132 & 70,387 & 31,411 & 5,142 & 63,693 & 3,131 & 8,106 & 61,903 & 21,289 & 60,858 & 1,999 & 15,956 & 2,139 & 310 & 371,009 \\
\hline 4 & Standalone Retail & 14,839 & 33,515 & 146,887 & 82,723 & 12,648 & 157,835 & 7,882 & 28,338 & 168,410 & 52,421 & 226, & 6,033 & 62,737 & 7,181 & 900 & $1,009,246$ \\
\hline 5 & Strip Mall & 9,094 & 16,772 & 65,543 & 41,385 & 6,838 & 67,525 & 1,490 & 7,061 & 66,706 & 13,316 & 67,664 & 1,057 & 10,099 & 454 & 89 & 375,093 \\
\hline 6 & Primary School & 4,213 & 10,870 & 61,754 & 29,519 & 99 & 62,485 & 1,990 & & 59,208 & 14,795 & 60,881 & 2,479 & 11,120 & 1,541 & 219 & 330,418 \\
\hline 7 & Secondary School & 10,600 & 15,188 & 100,737 & 54,194 & 7,244 & 125,250 & 4,185 & 16,049 & 133,185 & 28,960 & 150,955 & 5,687 & 27,474 & 4,984 & 817 & 685,508 \\
\hline 8 & Hospital & 2,669 & 6,336 & 31,675 & 18,032 & 2,584 & 30,950 & 1,473 & 7,005 & 40,719 & 14,448 & 53,727 & 1,567 & 14,631 & 2,230 & 87 & 228,131 \\
\hline 9 & Outpatient Health Care & 2,464 & 8,877 & 37,541 & 18,181 & 4,050 & 38,451 & 1,538 & 11,967 & 54,105 & 14,407 & 70,020 & 2,202 & 22,655 & 2,578 & 136 & 289,171 \\
\hline 10 & Restaurant & 597 & 1,625 & 6,985 & 3,140 & 381 & 7,361 & 385 & 676 & 8,412 & 2,054 & 9,465 & 265 & 2,052 & 242 & 9 & 43,650 \\
\hline 11 & Fast Food Restaurant & 517 & 1,343 & 6,061 & 4,178 & 457 & 6,735 & 352 & 947 & 5,887 & 1,697 & 8,501 & 205 & 1,678 & 236 & 15 & 38,809 \\
\hline 12 & Large Hotel & 7,193 & 8,264 & 41,074 & 52,454 & 6,986 & 42,021 & 2,449 & 8,106 & 63,408 & 13,212 & 60,813 & 3,817 & 14,994 & 2,534 & 237 & 327,562 \\
\hline 13 & Small hotel/n & 675 & 1,972 & 19,033 & 7,523 & 1,439 & 17,713 & 1,344 & 2,597 & 20,810 & 5,913 & 24,117 & 2,038 & 7,052 & 1,356 & 257 & 113,837 \\
\hline 14 & Non-refrigerate & 23,107 & 38,402 & 171,392 & 152,055 & 10,174 & 196,261 & 4,488 & 28,813 & 161,816 & 45,541 & 236,838 & 3,241 & 30,823 & 2,853 & 146 & $1,105,951$ \\
\hline 15 & High-rise ap & 100,657 & 5,046 & 100, & 49,002 & 11 & 43,1 & & 23, & & 7,632 & 76,963 & 1,062 & 8,245 & 557 & & 593,241 \\
\hline \multirow[t]{2}{*}{16} & Mid-rise apartment & 16,998 & 6,178 & 72,363 & 57,037 & 17,233 & 54,583 & 1,451 & 24,543 & 112,070 & 21,067 & 74,219 & 3,724 & 20,730 & 2,148 & & 484,343 \\
\hline & Covered by Prototypes & 214,472 & 196,858 & $1,006,763$. & 666,980 & 106,485 & 994,092 & 34,566 & 197,205 & \begin{tabular}{|l|}
$1,276,032$ \\
\end{tabular} & 287,386 & $1,281,276$ & 37,678 & 278,798 & 33,928 & 3,673 & $6,616,193$ \\
\hline & & & & & & & & & & & & & & & & & \\
\hline 17 & No Prototype & 58,017 & 51,941 & 217,098 & 181,396 & 34,618 & 235,402 & 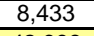 & 15 & & 71,223 & 01 & 11,863 & 81,900 & 11,131 & 663 & $\begin{array}{r}1,649,785 \\
8265,977\end{array}$ \\
\hline 18 & Total & 272,489 & 248,800 & $1,223,861$ & 848,376 & 141,102 & $1,229,495$ & 42,998 & 257,450 & $1,589,047$ & 358,608 & $1,594,116$ & 49,542 & 360,699 & 45,059 & 4,336 & $8,265,977$ \\
\hline
\end{tabular}

"No Prototype" Details

\begin{tabular}{|c|c|c|c|c|c|c|c|c|c|c|c|c|c|c|c|c|c|}
\hline & CBECS_Type & 1_moist & 2 dry & 2 moist & 3 dry & 3_marine & 3_moist & 4_dry & 4 marine & 4_moist & 5_dry & 5 moist & 6 dry & 6 moist & 7 & 8 & Total \\
\hline $17 \mathrm{~A}$ & Pubic Assembly & 5,780 & 11,902 & 54,924 & 39,534 & 7,971 & 59,601 & 2,958 & 10,150 & 75,740 & 19,412 & 96,753 & 4,250 & 22,021 & 3,615 & 344 & 414,953 \\
\hline $17 \mathrm{~B}$ & Food Sales & 730 & 3,117 & 10,919 & 8,101 & 1,111 & 13,098 & 369 & 2,439 & 21,101 & 3,511 & 25,512 & 632 & 5,556 & 672 & 123 & 96,990 \\
\hline $17 \mathrm{C}$ & Other & 46,107 & 25,102 & 96,856 & 108,826 & 21,895 & 87,257 & 2,456 & 39,096 & 147,589 & 27,767 & 124,936 & 3,445 & 34,097 & 3,946 & 48 & 769,423 \\
\hline 17D & Public Order and Safety & 899 & 5,474 & 16,198 & 9,532 & 1,827 & 20,742 & 1,010 & 2,745 & 21,363 & 7,445 & 22,523 & 1,475 & 8,688 & 1,881 & 105 & 121,907 \\
\hline $17 \mathrm{E}$ & Religious Worship & 1,848 & 3,383 & 27,776 & 9,057 & 950 & 44,869 & 1,167 & 3,958 & 38,363 & 9,030 & 32,371 & 1,531 & 9,075 & 734 & 34 & 184,143 \\
\hline $17 \mathrm{~F}$ & Service & 2,654 & 2,965 & 10,425 & 6,346 & 864 & 9,835 & 474 & 1,856 & 8,861 & 4,057 & 10,744 & 532 & 2,464 & 284 & 10 & 62,369 \\
\hline 17 & Total & 58017 & 51941 & 217098 & 181396 & 34618 & 235402 & 8433 & 60245 & 313016 & 71223 & 312839 & 11863 & 81900 & 11131 & 663 & 1649785 \\
\hline
\end{tabular}


Table 5 ASHRAE Prototype Building Construction Number of Projects

\begin{tabular}{|c|c|c|c|c|c|c|c|c|c|c|}
\hline Number & ASHRAE & 1 & 2 & 3 & 4 & 5 & 6 & 7 & 8 & Total \\
\hline 1 & Large Office & 37 & 123 & 231 & 390 & 182 & 40 & 5 & & 1,008 \\
\hline 2 & Medium Office & 178 & 1,558 & 2,389 & 2,397 & 2,492 & 713 & 82 & 13 & 9,822 \\
\hline 3 & Small Office & 682 & 10,700 & 14,396 & 11,148 & 11,742 & 2,258 & 265 & 28 & 51,219 \\
\hline 5 & Strip Mall & 82 & 1,655 & 1,818 & 1,221 & 1,539 & 311 & 19 & 2 & 6,647 \\
\hline 6 & Primary School & 136 & 1,644 & 2,574 & 2,068 & 2,250 & 493 & 50 & 7 & 9,222 \\
\hline 9 & Outpatient Health Care & 62 & 2,194 & 2,829 & 2,520 & 3,377 & 930 & 126 & 18 & 12,056 \\
\hline 10 & Restaurant & 80 & 1,293 & 1,747 & 1,481 & 1,813 & 325 & 34 & 1 & 6,774 \\
\hline 11 & Fast Food Restaurant & 94 & 1,903 & 2,488 & 1,707 & 2,469 & 367 & 49 & 4 & 9,081 \\
\hline 12 & Large Hotel & 41 & 333 & 542 & 550 & 540 & 157 & 25 & 2 & 2,190 \\
\hline 13 & Small hotel/motel & 41 & 734 & 915 & 883 & 1,082 & 346 & 61 & 9 & 4,071 \\
\hline & Covered by Prototypes & 2,943 & 38,343 & 50,426 & 43,049 & 48,838 & 10,657 & 1,349 & 165 & 195,770 \\
\hline 17 & No Prototype & 1,001 & 10,534 & 15,048 & 12,718 & 14,623 & 3,835 & 577 & 52 & 58,388 \\
\hline 18 & Total & 3,944 & 48,877 & 65,474 & 55,767 & 63,461 & 14,492 & 1,926 & 217 & 254,158 \\
\hline
\end{tabular}

\begin{tabular}{|c|l|c|c|c|c|c|c|c|c|c|}
\hline Number & \multicolumn{1}{|c|}{ CBECS_Type } & 1 & 2 & 3 & 4 & 5 & 6 & 7 & 8 & Total \\
\hline 17A & Pubic Assembly & 360 & 4,299 & 5,575 & 4,325 & 5,375 & 1,384 & 242 & 27 & 21,587 \\
\hline 17B & Food Sales & 23 & 688 & 965 & 953 & 1,237 & 294 & 29 & 3 & 4,192 \\
\hline 17C & Other & 341 & 1,121 & 2,148 & 2,074 & 1,834 & 604 & 99 & 5 & 8,226 \\
\hline 17D & Public Order and Safety & 66 & 830 & 1,304 & 1,171 & 1,381 & 486 & 94 & 9 & 5,341 \\
\hline 17E & Religious Worship & 110 & 2,088 & 3,171 & 2,821 & 2,929 & 738 & 76 & 4 & 11,937 \\
\hline 17F & Service & 101 & 1,508 & 1,885 & 1,374 & 1,867 & 329 & 37 & 4 & 7,105 \\
\hline & Total & 1,001 & 10,534 & 15,048 & 12,718 & 14,623 & 3,835 & 577 & 52 & 58,388 \\
\hline
\end{tabular}


Table 6 Prototype Building Construction Volume by State $\left(1,000 \mathrm{ft}^{2}\right)$

\begin{tabular}{|c|c|c|c|c|c|c|c|c|c|c|c|}
\hline $\begin{array}{c}\text { Project } \\
\text { State }\end{array}$ & Apartment & Healthcare & Hotel & Office & $\begin{array}{c}\text { Public } \\
\text { Assembly }\end{array}$ & Restaurant & Retail & School & Warehouse & \begin{tabular}{|c|} 
No \\
Prototype
\end{tabular} & Total \\
\hline $\mathrm{AK}$ & 201 & 1,401 & 1,357 & 2,428 & 1,190 & 137 & 2,240 & 2,484 & 1,356 & 2,787 & 15,581 \\
\hline $\mathrm{AL}$ & 8,619 & 7,587 & 9,184 & 16,191 & 6,876 & 1,821 & 26,748 & 16,514 & 9,060 & 18,729 & 121,329 \\
\hline AR & 1,272 & 5,000 & 5,198 & 6,962 & 3,611 & 829 & 14,624 & 13,936 & 3,609 & 8,768 & 63,810 \\
\hline$A Z$ & 11,223 & 16,195 & 11,272 & 43,383 & 12,701 & 2,918 & 52,646 & 24,692 & 40,052 & 40,986 & 256,068 \\
\hline $\mathrm{CA}$ & 105,071 & 35,633 & 33,678 & 99,228 & 33,281 & 5,747 & 114,344 & 76,262 & 143,853 & 132,882 & 779,978 \\
\hline $\mathrm{CO}$ & 21,885 & 14,926 & 10,735 & 23,225 & 7,618 & 2,142 & 31,177 & 17,804 & 16,582 & 31,094 & 177,186 \\
\hline CT & 6,582 & 4,333 & 5,261 & 6,651 & 5,485 & 698 & 13,403 & 12,856 & 8,798 & 13,679 & 77,746 \\
\hline $\mathrm{DC}$ & 12,636 & 769 & 1,199 & 15,734 & 1,202 & 38 & 1,122 & 2,051 & 363 & 8,934 & 44,047 \\
\hline $\mathrm{DE}$ & 755 & 1,672 & 1,330 & 2,410 & 1,282 & 173 & 2,551 & 3,126 & 1,722 & 3,480 & 18,501 \\
\hline $\mathrm{FL}$ & 230,315 & 36,591 & 32,071 & 97,212 & 33,622 & 7,299 & 128,133 & 83,524 & 104,327 & 137,213 & 890,306 \\
\hline $\mathrm{GA}$ & 39,780 & 16,699 & 16,254 & 39,076 & 13,043 & 3,563 & 63,430 & 60,062 & 80,180 & 57,586 & 389,672 \\
\hline $\mathrm{HI}$ & 13,773 & 979 & 989 & 1,838 & 630 & 95 & 2,939 & 985 & 1,417 & 5,220 & 28,865 \\
\hline IA & 1,542 & 6,875 & 4,598 & 10,749 & 7,069 & 796 & 14,534 & 13,586 & 6,688 & 11,426 & 77,863 \\
\hline ID & 2,506 & 4,001 & 2,375 & 7,703 & 2,478 & 493 & 7,526 & 6,847 & 3,876 & 5,343 & 43,147 \\
\hline $\mathrm{IL}$ & 78,609 & 18,998 & 14,037 & 31,542 & 18,451 & 2,497 & 60,928 & 33,180 & 69,674 & 44,977 & 372,893 \\
\hline IN & 3,875 & 18,600 & 9,210 & 18,791 & 14,242 & 2,747 & 35,539 & 27,535 & 40,591 & 25,992 & 197,123 \\
\hline $\mathrm{KS}$ & 1,057 & 5,734 & 3,795 & 9,442 & 3,178 & 1,039 & 12,076 & 8,892 & 5,521 & 7,216 & 57,950 \\
\hline $\mathrm{KY}$ & 2,888 & 8,150 & 6,922 & 12,558 & 8,185 & 1,489 & 17,941 & 13,672 & 21,538 & 11,906 & 105,248 \\
\hline LA & 1,823 & 7,001 & 8,689 & 12,647 & 6,386 & 1,454 & 18,681 & 9,061 & 10,886 & 14,841 & 91,469 \\
\hline MA & 31,854 & 7,832 & 9,516 & 11,868 & 6,808 & 1,306 & 19,079 & 14,599 & 9,197 & 26,742 & 138,802 \\
\hline $\mathrm{MD}$ & 35,967 & 8,750 & 8,888 & 30,163 & 6,242 & 1,173 & 16,672 & 16,432 & 21,414 & 36,463 & 182,163 \\
\hline $\mathrm{ME}$ & 687 & 2,245 & 1,791 & 2,411 & 1,441 & 368 & 6,088 & 3,374 & 3,021 & 5,320 & 26,745 \\
\hline $\mathrm{MI}$ & 4,800 & 19,346 & 7,671 & 18,251 & 14,629 & 2,153 & 34,934 & 22,151 & 9,305 & 26,283 & 159,523 \\
\hline MN & 15,465 & 10,954 & 5,093 & 17,575 & 5,673 & 1,098 & 22,985 & 12,643 & 8,643 & 25,212 & 125,342 \\
\hline $\mathrm{MO}$ & 9,420 & 10,121 & 9,483 & 13,197 & 8,395 & 1,705 & 27,054 & 17,497 & 8,818 & 21,226 & 126,915 \\
\hline MS & 1,613 & 3,618 & 5,153 & 6,789 & 4,423 & 587 & 12,551 & 7,999 & 17,146 & 7,447 & 67,326 \\
\hline MT & 481 & 1,313 & 1,265 & 1,602 & 1,007 & 195 & 2,723 & 1,871 & 821 & 1,533 & 12,810 \\
\hline $\mathrm{NC}$ & 17,294 & 14,663 & 12,678 & 36,249 & 12,044 & 2,481 & 48,139 & 36,794 & 20,559 & 37,891 & 238,792 \\
\hline ND & 76 & 1,265 & 982 & 1,490 & 1,221 & 155 & 3,567 & 1,871 & 617 & 1,077 & 12,320 \\
\hline $\mathrm{NE}$ & 1,586 & 4,880 & 3,263 & 6,790 & 3,562 & 577 & 12,369 & 5,533 & 3,660 & 7,279 & 49,498 \\
\hline $\mathrm{NH}$ & 1,523 & 2,440 & 2,437 & 2,974 & 1,653 & 548 & 6,970 & 4,421 & 2,059 & 4,717 & 29,741 \\
\hline $\mathrm{NJ}$ & 30,209 & 8,563 & 10,145 & 13,295 & 8,335 & 1,210 & 26,842 & 28,280 & 32,383 & 27,841 & 187,103 \\
\hline NM & 957 & 2,655 & 4,499 & 6,636 & 3,770 & 670 & 8,235 & 8,097 & 3,142 & 5,290 & 43,950 \\
\hline $\mathrm{NV}$ & 30,856 & 5,684 & 31,894 & 17,504 & 12,863 & 1,691 & 25,644 & 10,337 & 17,969 & 34,776 & 189,218 \\
\hline NY & 125,095 & 17,639 & 21,083 & 35,842 & 11,572 & 2,259 & 39,107 & 24,186 & 13,845 & 36,104 & 326,732 \\
\hline $\mathrm{OH}$ & 6,832 & 26,393 & 9,959 & 28,780 & 13,630 & 4,004 & 55,245 & 47,919 & 36,400 & 34,909 & 264,071 \\
\hline OK & 1,242 & 8,547 & 5,511 & 8,216 & 9,450 & 1,523 & 14,686 & 12,691 & 10,032 & 13,680 & 85,577 \\
\hline OR & 13,492 & 9,885 & 3,878 & 9,927 & 4,118 & 728 & 14,881 & 7,004 & 12,291 & 17,738 & 93,941 \\
\hline $\mathrm{PA}$ & 16,177 & 20,535 & 15,135 & 26,096 & 14,577 & 2,361 & 40,489 & 39,397 & 37,805 & 38,280 & 250,852 \\
\hline $\mathrm{RI}$ & 2,559 & 649 & 2,069 & 2,707 & 877 & 278 & 2,990 & 2,125 & 1,228 & 2,540 & 18,021 \\
\hline SC & 21,321 & 8,033 & 6,056 & 16,562 & 5,801 & 1,810 & 27,984 & 23,920 & 11,848 & 22,949 & 146,284 \\
\hline SD & 142 & 1,285 & 922 & 2,767 & 1,354 & 138 & 3,668 & 2,884 & 950 & 2,202 & 16,312 \\
\hline $\mathrm{TN}$ & 10,621 & 11,152 & 7,347 & 24,718 & 7,891 & 2,145 & 38,548 & 19,476 & 29,045 & 25,152 & 176,095 \\
\hline $\mathrm{TX}$ & 59,723 & 48,519 & 38,437 & 89,641 & 35,794 & 9,142 & 141,238 & 136,629 & 114,193 & 104,156 & 777,473 \\
\hline UT & 6,695 & 6,123 & 3,384 & 14,698 & 5,110 & 822 & 15,331 & 13,657 & 13,716 & 12,926 & 92,462 \\
\hline VA & 37,694 & 10,887 & 14,646 & 39,749 & 11,794 & 2,149 & 32,438 & 25,691 & 19,659 & 47,422 & 242,129 \\
\hline VT & 1,736 & 1,063 & 1,030 & 1,214 & 765 & 68 & 674 & 1,463 & 946 & 1,777 & 10,737 \\
\hline WA & 36,566 & 11,683 & 9,378 & 26,209 & 8,964 & 1,147 & 26,954 & 19,817 & 20,236 & 38,731 & 199,685 \\
\hline WI & 9,754 & 16,350 & 6,273 & 16,751 & 8,030 & 1,474 & 26,793 & 12,148 & 9,497 & 21,325 & 128,395 \\
\hline WV & 697 & 2,314 & 1,592 & 2,081 & 1,259 & 421 & 7,191 & 5,215 & 1,930 & 3,098 & 25,797 \\
\hline WY & 42 & 774 & 1,787 & 713 & 1,370 & 97 & 1,696 & 2,737 & 718 & 2,453 & 12,387 \\
\hline Total & $1,077,585$ & 517,302 & 441,399 & 991,233 & 414,953 & 82,459 & $1,384,339$ & $1,015,925$ & $1,063,186$ & $1,277,597$ & $8,265,977$ \\
\hline
\end{tabular}




\section{References}

ASHRAE. 2004. "ANSI/ASHRAE/IESNA Standard 90.1-2004. Energy Standard for Buildings Except Low-

Rise Residential Buildings." American Society of Heating, Refrigerating and Air-Conditioning Engineers, Inc., Atlanta, Georgia.

CBECS. 2003. Commercial Buildings Energy Consumption Survey 2003, Energy Information

Administration of U.S. Department of Energy, Washington, D.C. Last accessed on August 3, 2009 at http://www.eia.doe.gov/emeu/cbecs/contents.html

Deru, M., B. Griffith and P. Torcellini. 2006. Establishing Benchmarks for DOE Commercial Building R\&D and Program Evaluation. National Renewable Energy Laboratory, Golden, Colorado. 